\title{
Suppression of spermatogenesis before grafting increases survival and supports resurgence of spermatogenesis in adult mouse testis
}

\author{
Lucía Arregui, Ph.D. ${ }^{a, b}$, Rahul Rathi, Ph.D. ${ }^{a}$, Mark Modelski, B.S. ${ }^{a}$, Wenxian Zeng, Ph.D. ${ }^{a}$, \\ Eduardo R. S. Roldan, Ph.D. ${ }^{b}$, and Ina Dobrinski, Ph.D. ${ }^{a}$ \\ ${ }^{a}$ Center for Animal Transgenesis and Germ Cell Research, University of Pennsylvania, Kennett \\ Square, Pennsylvania

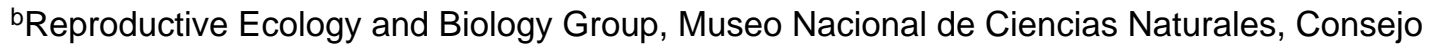 \\ Superior de Investigaciones Científicas, Madrid, Spain
}

\begin{abstract}
Objective-To test whether absence of complete spermatogenesis in mature testicular tissue before grafting will increase graft survival.

Design-Prospective experimental study.

Setting-Laboratory.

Animal(s)—Donor testes were obtained from adult untreated mice, adult mice rendered cryptorchid, and adult mice treated with a GnRH antagonist (acyline).

Intervention(s) -Donor testes were ectopically grafted to nude mice and recovered at three time points.
\end{abstract}

Main Outcome Measure(s)-Most advanced germ cell type and presence of spermatogonia were assessed. Donor testes and grafts were analyzed by histology and by immunocytochemistry for ubiquitin C-terminal hydrolase-L1 to mark germ cells.

Result(s)-Suppression of spermatogenesis by inducing cryptorchidism or acyline treatment resulted in improved survival of grafted tissue compared with controls and recovery of complete spermatogenesis, whereas control testis grafts mostly degenerated and did not restore complete spermatogenesis.

Conclusion(s)-These results indicate that complete spermatogenesis at the time of grafting has a negative effect on graft survival. Grafting of adult testis tissue from donors with suppressed spermatogenesis leads to spermatogenic recovery and may provide a tool to study and preserve

Copyright @2012 American Society for Reproductive Medicine, Published by Elsevier Inc.

Reprint requests: Ina Dobrinski, Ph.D., University of Calgary, Department of Comparative Biology and Experimental Medicine, 3330 Hospital Drive NW, Calgary, Alberta T2N 4N1, Canada (idobrins@ucalgary.ca).

L.A.'s current address is Department of Biology, Universidad Autónoma de Madrid, Madrid, Spain.

L.A. has nothing to disclose. R.R. has nothing to disclose. M.M. has nothing to disclose. W.Z. has nothing to disclose. E.R.S.R. has nothing to disclose. I.D. has nothing to disclose. 
fertility and for conservation of genetic resources in individuals that lack complete germ cell differentiation.

\section{Keywords}

Grafting; acyline; cryptorchidism; spermatogenesi

Reproductive biotechnology plays an important role in the study and preservation of fertility. In adult males, the most common technology to preserve fertility is cryopreservation of spermatozoa. However, in cases in which collection of spermatozoa is not possible, such as in men rendered azoospermic by disease or cancer treatment (1) or in species with seasonal reproductive patterns outside the mating season (2), xenografting could be a method to obtain sperm. Transplantation of adult testis tissue could also be useful to study mechanisms that cause disturbance of spermatogenesis (3).

Xenografting of immature testis tissue results in complete spermatogenesis in donor tissue from different mammalian species (4-11). In contrast, in most studies with adult testis tissue, xenografting led to the degeneration of the transplanted tissue or the survival of tubules with Sertoli cells only (12-15). In human adult testis grafts, spermatogonia were observed in some cases $(12,13)$, and in mature horse and some mouse testis grafts spermatogenesis proceeded but was arrested at the spermatocyte stage $(5,6)$.

The differential potential of immature and adult testis tissue to survive after grafting is not completely understood, but some hypotheses have been proposed $(5,15)$. Adult tissue may be more sensitive than young tissue to transient ischemia associated with the grafting procedure, or mature tissue may be less effective in inducing angiogenesis than immature testis tissue. Graft development could also be impaired because mature Sertoli cells have lost the ability to divide. Our previous work suggested that degeneration of adult testis tissue grafts is related to the degree of sperm production and structural organization of the seminiferous tubules (15). Higher metabolic demands to support the high rate of cell division and differentiation during active spermatogenesis could render mature tissue more sensitive to hypoxia than testis tissue with no or low levels of spermatogenesis (15). Therefore, suppression of spermatogenesis in adult testis tissue before grafting would improve survival of the tissue as a graft.

There are different hormonal or physical methods to suppress spermatogenesis in testis tissue. Many hormonal treatments have been tested to develop an effective male contraceptive. Acyline is a GnRH antagonist that competitively inhibits the action of GnRH at pituitary receptor sites. Treatment with acyline caused suppression of $\mathrm{T}$ and gonadotropins and decreased sperm count and motility in different species (16-19).

Spermatogenesis is also suppressed in cryptorchid testes. When testes are retained in the abdominal cavity, exposure to core body temperature results in degeneration of differentiating germ cells and infertility in various species (20). Experimentally induced cryptorchidism in mice has been used to deplete the germinal epithelium of differentiating cells (21). Treatment with a GnRH antagonist and cryptorchidism suppress spermatogenesis, but once permissive conditions are restored, spermatogenesis will be reinitiated from 
spermatogonia retained in the suppressed testis, and differentiation of germ cells can take place $(17,22)$.

Here we test the hypothesis that suppression of spermatogenesis by treatment with acyline or by induced cryptorchidism increases survival and germ cell differentiation in allografts from adult mouse testis.

\section{MATERIALS AND METHODS}

All animal procedures were approved by and performed under the guidance of the Institutional Animal Care and Use Committee at the University of Pennsylvania.

\section{Donor Tissue}

Testes from 15-week-old B6C3F1 mice ( $\mathrm{n}=3$ mice) served as untreated control tissue.

Male B6C3F1 mice at 6 weeks of age $(\mathrm{n}=9)$ were anesthetized, and cryptorchidism was induced (23). Testes were recovered 2 months later.

Male B6C3F1 mice at 6 weeks of age were treated SC with $5 \mathrm{mg}$ acyline $/ \mathrm{kg}(\mathrm{n}=9)$ or 10 $\mathrm{mg}$ acyline/kg ( $\mathrm{n}=5)$ once every 2 weeks for 3 months (19) (Dr. Marvin L. Meistrich, personal communication, September 2007). Testes were recovered 1 week after the last injection.

\section{Grafting of Donor Tissue}

Donor mice were sacrificed by $\mathrm{CO}_{2}$ inhalation, testis weight was recorded, and testes were decapsulated, cut into small fragments (approximately $1 \mathrm{~mm}^{3}$ ), and maintained in Dulbecco's modified Eagle medium on ice until grafting. Male immunodeficient NCR-nude mice ( $\mathrm{n}=9$ per treatment group) at 6-8 weeks of age were anesthetized, castrated, and during the same surgery six fragments of donor testis tissue were implanted under their back skin.

\section{Donor and Graft Tissue Recovery}

Three recipient mice from each group were killed at 1,2, and 3 months after grafting by $\mathrm{CO}_{2}$ inhalation. Mice were weighed, the back skin was removed, and grafts were recovered. Seminal vesicles were weighed as an indicator of T secretion by grafts (24). Pieces of testicular tissue from donors and the recovered grafts were fixed in Bouin's solution after dissection and processed for histology as described previously (25).

\section{Analysis of Testicular Tissue}

A hematoxylin and eosin-stained section from each donor and graft testicular tissue was examined. All seminiferous tubules present were counted and classified according to the most advanced germ cell stage present or as degenerated tubule when they showed hyalinization (Fig. 1A). When no tubular structure was found in the graft, it was considered as completely degenerated. In tubules with differentiated germ cells, pachytene spermatocytes were identified according to cell size and distinctive chromatin structure, and 
round spermatids according to their adluminal position, smaller cell size, clear cytoplasm, and the presence of a condensed nucleus.

To distinguish between tubules containing spermatogonia as most advanced germ cell type and those containing Sertoli cells only in tubules where no meiotic or postmeiotic germ cells were detected by examination of histologic sections, immunostaining for ubiquitin Cterminal hydrolase-L1 (UCH-L1) was performed to label spermatogonia (Fig. 1B). Slides were deparaffinized, rehydrated, and rinsed in distilled water. Then, samples were permeabilized in $0.5 \%$ Triton X-100 (EMD) in phosphate-buffered saline (PBS) for 10 minutes at room temperature. Endogenous peroxidase activity was blocked by treating the samples with $3 \% \mathrm{H}_{2} \mathrm{O}_{2}$ in distilled water for 10 minutes. After washing in PBS, sections were incubated with $3 \%$ bovine serum albumin in PBS for 1.5 hours at room temperature to block unspecific antibody binding. Subsequently, samples were incubated overnight at $4^{\circ} \mathrm{C}$ in a humidified chamber with the first antibody: polyclonal anti-UCH-L1 antibody (AbD Serotec) diluted 1:500 in 3\% bovine serum albumin. The next day, the slides were washed with PBS and treated for 1 hour with the secondary antibody (peroxidase-conjugated affinipure donkey anti-rabbit IgC; Jackson ImmunoResearch) diluted 1:1,000 in PBS. Finally, samples were washed, treated with Novared (Vector Laboratories) for 1 minute to detect peroxidase activity, counterstained with hematoxylin, and mounted.

\section{Statistical Analysis}

Statistical analysis was performed with SPSS 14.0 for Windows. Data from all grafts recovered from the back of each individual mouse were pooled, so each mouse was considered as the experimental unit. Kruskal-Wallis and Mann-Whitney tests were used to analyze the results. Data are expressed as means \pm SEM, and $P<.05$ was considered significant.

\section{RESULTS \\ Donor Tissue}

The testis weight in B6C3F1 control animals (untreated 15-week-old mice) was $145.5 \pm 3.3$ $\mathrm{mg}$, and the testes contained full spermatogenesis ( $89.0 \%$ of tubules had elongated spermatids; Fig. 2, Table 1).

The total percentage of recovered grafts for all three time points was $48.2 \%$, and $30.8 \%$ of them presented no seminiferous tubules and consequently were classified as completely degenerated grafts (Table 1). In grafts from control tissue, the percentage of degenerated tubules was always higher than $64 \%$, but tubules with germ cells were observed at every time point. At 3 months after grafting fewer than $3 \%$ of seminiferous tubules had germ cells (Figs. 2 and 3A, Table 1).

B6C3F1 mice cryptorchid testes after 2 months inside the abdominal cavity weighed $35.5 \pm$ $1.0 \mathrm{mg}$, significantly less than the control testis $(145.5 \mathrm{mg} \pm 3.3, P<.001)$, and had $1.5 \%$ of tubules presenting round spermatids as the most advanced germ cell (Fig. 2, Table 1). 
The overall percentage of grafts recovered after transplantation of cryptorchid testes was $77.8 \%$, and $11.9 \%$ of them contained no tubules (Fig. 2, Table 1). The histologic appearance of the grafts at 1,2, and 3 months after grafting was similar, with nearly $50 \%$ degenerated tubules, $30 \%$ Sertoli cells only tubules, and $15 \%$ tubules showing germ cells. At 3 months after grafting, spermatogenesis had progressed through meiosis, and round and elongated spermatids were present (Figs. 2 and 3B, Table 1).

In mice injected with $5 \mathrm{mg}$ acyline $/ \mathrm{kg}$, spermatogenesis was not completely suppressed, and elongated spermatids were found in $76.9 \%$ of tubules (Fig. 2, Table 1). However, testis weight was significantly lower than in controls (mean $74.8 \mathrm{mg} \pm 0.9$ vs. $145.5 \mathrm{mg} \pm 3.3 \mathrm{in}$ controls, $P<.001$ ). Testes from mice treated with $10 \mathrm{mg}$ acyline $/ \mathrm{kg}$ were the smallest of all treatments groups (mean $7.9 \mathrm{mg} \pm 0.5, P<.001$ ), they contained no elongated spermatids, and $13.6 \%$ of tubules contained round spermatids as the most advanced germ cell (Fig. 2, Table 1). The percentage of recovered grafts in mice carrying low-dose acyline-treated tissue $(72.2 \%)$ was not statistically different from the control, but graft recovery was higher in mice with grafts from donors treated with high-dose acyline $(88.9 \% ; P<.05)$. Although $12.5 \%$ of recovered grafts from donor mice injected with $5 \mathrm{mg}$ acyline $/ \mathrm{kg}$ were degenerated, for donor mice treated with $10 \mathrm{mg}$ acyline $/ \mathrm{kg}$ only $5.4 \%$ of all recovered grafts were degenerated (Fig. 2, Table 1).

Grafts from donor mice treated with low-dose acyline contained more than $60 \%$ degenerated tubules at all time points (Fig. 2, Table 1). At 1 and 2 months after grafting, some survival and differentiation of germ cells had occurred, and elongated spermatids were present. However, at 3 months after grafting more than $85 \%$ of tubules were degenerated, although some round spermatids were still observed (Figs. 2 and 3C, Table 1).

Grafts from donor mice injected with high-dose acyline contained fewer than $40 \%$ degenerated tubules (Fig. 2, Table 1). Round spermatids were present at 1 month after grafting, and spermatogenesis progressed over time with an increased percentage of tubules with postmeiotic germ cells (Figs. 2 and 3D, Table 1). Dilated tubules, defined as tubules in which the lumen occupies the majority of the cross-sectional area and the germinal epithelium is reduced, were observed at 3 months after grafting, as was previously found in grafts from immature mouse testis (24) (Fig. 2, Table 1).

\section{Analysis of Seminal Vesicle Weight}

Testosterone secretion was estimated according to the weight of the seminal vesicles. There were no statistical differences in seminal vesicle weight between time points for any treatment, or between treatments at any time point, except in mice with grafts treated with high doses of acyline, in which seminal vesicle weight was higher at 3 months than at 1 month after grafting $(195.4 \pm 35.0 \mathrm{mg}$ at 3 months vs. $50.6 \pm 22.8 \mathrm{mg}$ at 1 month, respectively; $P<.05)$.

\section{DISCUSSION}

The present study demonstrates that adult testis tissue is able to survive and germ cells can proliferate and differentiate in tissue grafted ectopically to castrated host mice. Suppressed 
spermatogenesis, by inducing cryptorchidism or treatment with high doses of acyline, resulted in improved survival of the grafted tissue and recovery of spermatogenesis compared with control tissue. Similarly, grafts of human testis tissue with spermatogenic dysfunction and of cryptorchid horse testis tissue survived better than those of normal adult human or equine testes $(3,13)$. Hence, the reason adult testis grafts degenerate when transplanted seems to depend on the presence of spermatogenesis, and consequently degeneration of grafted tissue is not inherent to the adult testis tissue. Therefore, the population of spematogonia in an adult testis tissue retains the potential to proliferate and differentiate when grafted, similar to spermatogonia present in immature testis. To our knowledge this is the first report of complete spematogenesis occurring in fresh adult testis tissue graft.

It was proposed that the progression of degeneration of mature testicular tissue grafts is related to the degree of spermatogenesis in donor tissue at the time of grafting $(12,15)$. The results of the present study support the hypothesis of a correlation between the presence of spermatogenesis and degeneration of grafted adult testis. The testis is an organ with a high sensitivity to ischemia (26). The high cell proliferation rate makes the adult testis dependent on high blood supply and, consequently, very susceptible to the period of ischemia during the grafting procedure.

Interestingly, different treatments to suppress spermatogenesis resulted in different levels of graft survival and germ cell differentiation. Cryptorchid tissue revealed a more complete suppression of spermatogenesis, on the basis of the lowest percentage of seminiferous tubules with the most advanced germ cell stages, compared with testis tissue from mice injected with $10 \mathrm{mg}$ acyline $/ \mathrm{kg}$. However, grafts from testis tissue treated with high doses of acyline had a higher percentage of recovered grafts, nondegenerated tubules, and progression of spermatogenesis. Suppression of $\mathrm{T}$ production can promote recovery of spermatogenesis when used before or after irradiation $(27,28)$, chemical damage with busulfan (29), procarbazine (30), or CDB-4022 (31) in mice mutant for the juvenile spermatogonial depletion (jsd) gene (32) and in induced cryptorchids (33). This indicates that suppression of $\mathrm{T}$ production has a beneficial effect on the restoration of spermatogenic activity regardless of the mechanism of impairment (33). On the basis of this assumption, acyline-treated tissue that was exposed to a lower level of $\mathrm{T}$ than cryptorchid testis tissue may contain a more conducive microenvironment for spermatogonial differentiation. Moreover, cryptorchidism may have an adverse effect on Sertoli cells as well as on differentiated germ cells, with formation of vacuoles between Sertoli cells, increased volume of lipid droplets, and wider Sertoli cell junctions (34) that could be negatively affecting the development of the graft and contribute to degeneration.

The weight of the donor testis was different among treatments. Testis weight in mice injected with low doses of acyline was half that of the control testes. However, both control and low-dose acyline-treated testes maintained active spermatogenesis, and more than $75 \%$ of the tubules showed elongated spermatids as the most advanced germ cell. The difference in testis weight could be due to the differences in interstitial tissue volume. Mice injected with $5 \mathrm{mg}$ acyline/kg likely experienced a reduction in the secretion of FSH and LH and a decrease of T production (19). Yet, under physiologic conditions, the concentration of T 
inside the seminiferous tubules is higher than the concentration needed for spermatogenesis to occur (35). Therefore, decreased production of T may reflect a reduction in the volume of Leydig cells but did not adversely affect spermatogenesis. Suppression of T could also have affected secretory activity of Sertoli and germ cells (36), decreasing production of seminiferous tubule fluid and testicular weight (18). Cryptorchid testicular tissue weight was half that of testes from mice treated with low-dose acyline. Luteinizing hormone and $\mathrm{T}$ serum levels and the interstitial tissue in cryptorchid mice are very similar to normal mice testes (37). The reduction of cryptorchid testes weight is therefore mainly due to the loss of advanced germ cells (38). Finally, mice treated with high-dose acyline had the lightest testis because both effects described above-reduction in synthesis of $\mathrm{T}$ and loss of advanced germ cells-occurred in these testes.

Overall, our findings support the notion that grafting of adult tissue could be an alternative method to recover sperm from adults with nonobstructive azoospermia. Patients with extragonadal causes of maturation arrest, germ cell aplasia, or hypospermatogenesis such as idiopathic hypogonadotropic hypogonadism, or after vasectomy or testicular artery torsion, and some cases of Klinefelter syndrome could be candidates for this technique, whereas tissue grafts from fertile adults or men with obstructive azoospermia will likely degenerate. Transplantation of human testis from patients who underwent gender-transforming surgery resulted in partial degeneration of the tissue, and differentiated germ cells were not found (13). However, the exposure of the donor tissue to estrogens and suppression of the pituitary function for a long time could have damaged the seminiferous tubules. Testis tissue xenografting could also be used as an accessible model to understand the basis of testicular dysfunction and design treatments. Grafting of immature rhesus monkey testis tissue has been used as a model to evaluate the cytotoxic effect of busulfan on testicular function (39) and to analyze the effect of supplementation with gonadotropins to accelerate maturation of Sertoli cells and onset of spermatogenesis (40). Xenografting of testicular tissue can provide a framework to study extragonadal causes for disruption of spermatogenesis and an accessible system to devise strategies to manipulate the extragonadal environment.

Finally, in many mammalian species, testis function varies with season, ranging from complete suppression of spematogenesis outside of the mating season in some species to normal sperm production during the entire year in others (2). Possibly, testis tissue grafting could be a tool to obtain sperm for genetic conservation in species with a prominent seasonal reproductive pattern and lack of elongated spermatids during some of the year.

Sperm obtained by testis tissue xenografting should be used by intracytoplasmic sperm injection for fertilization because lack of maturation in the epididymis precludes motility. Intracytoplasmic sperm injection is currently a routine technique for assisted reproduction in humans and has been applied successfully in domestic mammals (41-43). Viable piglets have been born after intracytoplasmic sperm injection with sperm produced by testis tissue xenografting and embryo transfer (44). Although in the current experiments the number of elongated spermatids present in grafts was low at 3 month after grafting, the possibility of using round spermatids for fertilization by round spermatid injection opens new possibilities for the application of this technique. Round spermatid nucleus injection is still considered an 
experimental technique in humans (45), but birth of a healthy human infant and other species has been reported (46-48).

In conclusion, complete spermatogenesis can be supported from adult spermatogonia when mature testicular tissue is grafted to host mice. Spermatogenic activity at the time of grafting has a negative effect on the survival of the grafts, whereas suppressed spermatogenesis before grafting leads to the resurgence and completion of spermatogenesis in adult mouse testis allografts. Therefore, xenografting of adult testicular tissue from donors with impaired spermatogenesis may provide a tool for fertility preservation, study of infertility, and genetic conservation.

\section{Acknowledgments}

The authors thank Terry Jordan and her staff for animal care, Dr. Lin Tang for advice on immunohistochemistry, Jose Benavent-Corai for his help with statistical analyses, and the Contraception and Reproductive Health Branch of the National Institutes of Health for providing the acyline.

This work was supported by grant no. 2R01 RR17359-08 from the National Institutes of Health/National Center for Research Resources, grant no. 2007-35203-18213 from the United States Department of Agriculture/Cooperative State Research, Education and Extension Service/National Research Initiative Competitive Grants Program (USDA/CSREES/NRICGP), and grant nos. CGL2006-13340/BOS and CGL2009-11606 from the Spanish Ministry of Education and Science. L.A. was a recipient of a predoctoral studentship from the Spanish Ministry of Education (BES-2004-4112).

\section{REFERENCES}

1. Orwig KE, Schlatt S. Cryopreservation and transplantation of spermatogonia and testicular tissue for preservation of male fertility. J Natl Cancer Inst Monogr. 2005; 34:51-56. [PubMed: 15784824]

2. Blottner S, Hingst O, Meyer HHD. Inverse relationship between testicular proliferation and apoptosis in mammalian seasonal breeders. Theriogenology. 1995; 44:320-328.

3. Turner RM, Rathi R, Honaramooz A, Zeng W, Dobrinski I. Xenografting restores spermatogenesis to cryptorchid testicular tissue but does not rescue the phenotype of idiopathic testicular degeneration in the horse (Equus caballus). Reprod Fertil Dev. 2010; 22:673-683. [PubMed: 20353727]

4. Honaramooz A, Snedaker A, Boiani M, Schöler H, Dobrinski I, Schlatt S. Sperm from neonatal mammalian testes grafted in mice. Nature. 2002; 418:778-781. [PubMed: 12181567]

5. Schlatt S, Kim SS, Gosden R. Spermatogenesis and steroidogenesis in mouse, hamster and monkey testicular tissue after cryopreservation and heterotopic grafting to castrated hosts. Reproduction. 2002; 124:339-346. [PubMed: 12201807]

6. Rathi R, Honaramooz A, Zeng W, Turner R, Dobrinski I. Germ cell development in equine testis tissue xenografted into mice. Reproduction. 2006; 131:1-9. [PubMed: 16388003]

7. Arregui L, Rathi R, Megee SO, Honaramooz A, Gomendio M, Roldan E, et al. Xenografting of sheep testis tissue and isolated cells as a model for preservation of genetic material from endangered ungulates. Reproduction. 2008; 136:85-93. [PubMed: 18390693]

8. Shinohara T, Inoue K, Ogonuki N, Kanatsu-Shinohara M, Miki H, Nakata K, et al. Birth of offspring following transplantation of cryopreserved immature pieces and in-vitro microinsemination. Hum Reprod. 2002; 17:3039-3045. [PubMed: 12456600]

9. Honaramooz A, Li MW, Penedo MCT, Meyers S, Dobrinski I. Accelerated maturation of primate testis by xenografting into mice. Biol Reprod. 2004; 70:1500-1503. [PubMed: 14736818]

10. Oatley JM, de Avila DM, Reeves JJ, McLean DJ. Spermatogenesis and germ cell transgene expression in xenografted bovine testicular tissue. Biol Reprod. 2004; 71:494-501. [PubMed: 15070832] 
11. Snedaker AK, Honaramooz A, Dobrinski I. A game of cat and mouse: xenografting of testis tissue from domestic kittens results in complete cat spermatogenesis in a mouse host. J Androl. 2004; 25:926-930. [PubMed: 15477365]

12. Geens M, de Block G, Goossens E, Frederickx V, van Steirteghem A, Tournaye H. Spermatogonial survival after grafting human testicular tissue to immunodeficient mice. Hum Reprod. 2006; 21:390-396. [PubMed: 16311289]

13. Schlatt S, Honaramooz A, Ehmcke J, Goebell PJ, Rübben H, Dhir R, et al. Limited survival of adult human testicular tissue as ectopic xenograft. Hum Reprod. 2006; 21:384-389. [PubMed: 16239313]

14. Kim Y, Selvaraj V, Pukazhenthi B, Travis AJ. Effect of donor age on success of spermatogenesis in feline testis xenografts. Reprod Fertil Dev. 2007; 19:869-876. [PubMed: 17897590]

15. Arregui L, Rathi R, Zeng W, Honaramooz A, Gomendio M, Roldan ERS, et al. Xenografting of adult mammalian testis tissue. Anim Reprod Sci. 2008; 106:65-76. [PubMed: 17512146]

16. Herbst KL, Coviello AD, Page S, Amory JK, Anawalt BD, Bremner WJ. A single dose of the potent gonadotropin-releasing hormone antagonist acyline suppresses gonadotropins and testosterone for 2 weeks in healthy young men. J Clin Endocrinol Metab. 2004; 89:5959-5965. [PubMed: 15579744]

17. Valiente C, Corrada Y, de la Sota PE, Gerez PG, Gobello C. Effect of the GnRH antagonist, acyline, on canine testicular characteristics. Theriogenology. 2007; 68:687-692. [PubMed: 17586037]

18. Porter KL, Shetty G, Meistrich ML. Testicular edema is associated with spermatogonial arrest in irradiated rats. Endocrinology. 2006; 147:1297-1305. [PubMed: 16306082]

19. Shetty G, Weng CCY, Porter KL, Zhang Z, Pakarinen P, Kumar TR, et al. Spermatogonial differentiation in juvenile spermatogonial depletion (jsd) mice with androgen receptor or folliclestimulating hormone mutations. Endocrinology. 2006; 147:3563-3570. [PubMed: 16627582]

20. VanDemark, NL.; Free, MJ. Temperature effects. In: Johnson, AD.; Gomes, WR.; VanDemark, NL., editors. The testis, Vol. III. New York: Academic Press; 1970. p. 233-312.

21. Nishimune Y, Haneji T. Testicular DNA synthesis in vivo: comparison between unilaterally cryptorchid testis and contralateral intact testis in mouse. Arch Andrology. 1981; 6:61-65.

22. Nishimune Y, Haneji T, Aizawa S. Testicular DNA synthesis in vivo: changes in DNA synthetic activity following artificial cryptorchidism and its surgical reversal. Fertil Steril. 1981; 35:359362. [PubMed: 6110567]

23. Nishimune Y, Aizawa S, Komatsu T. Testicular germ cell differentiation in vivo. Fertil Steril. 1978; 29:95-102. [PubMed: 23321]

24. Schlatt S, Honaramooz A, Boinai M, Schöler HR, Dobrinski I. Progeny from sperm obtained after ectopic grafting of neonatal mouse testes. Biol Reprod. 2003; 68:2331-2335. [PubMed: 12606381]

25. Rodriguez Sosa JR, Rathi R, Wang Z, Dobrinski I. Development of bovine fetal testis tissue after ectopic xenografting in mice. J Androl. 2011; 32:271-278. [PubMed: 20930193]

26. Nugent D, Meirow D, Brook PF, Aubard Y, Gosden RG. Transplantation in reproductive medicine: previous experience, present knowledge and future prospects. Hum Reprod. 1997; 3:267-280.

27. Meistrich ML, Kangasniemi M. Hormone treatment after irradiation stimulates recovery of rat spermatogenesis from surviving spermatogonia. J Androl. 1997; 18:80-87. [PubMed: 9089071]

28. Meistrich ML, Wilson G, Kangasniemi M, Huhtaniemi I. Mechanism of protection of rat spermatogenesis by hormonal pretreatment: stimulation of spermatogonial differentiation after irradiation. J Androl. 2000; 21:464-469. [PubMed: 10819455]

29. Udagawa K, Ogawa T, Watanabe T, Yumura Y, Takeda M, Hosaka M. GnRH analog, leuprorelin acetate, promotes regeneration of rat spermatogenesis after severe chemical damage. Int J Urol. 2001; 8:615-622. [PubMed: 11903688]

30. Kangasniemi M, Wilson G, Huhtaniemi I, Meistrich ML. Protection against procarbazine-induced testicular damage by GnRH-agonist and antiandrogen treatment in the rat. Endocrinology. 1995; 136:3677-3680. [PubMed: 7628410] 
31. Hild SA, Attardi BJ, Reel JR. The ability of a gonadotropin-releasing hormone antagonist, acyline, to prevent irreversible infertility induced by the indenopyridine, CDB-4022, in adult male rats: the role of testosterone. Biol Reprod. 2004; 71:348-358. [PubMed: 15044265]

32. Matsumiya K, Meistrich ML, Shetty G, Dohmae K, Tohda A, Okuyama A, et al. Stimulation of spermatogonial differentiation in juvenile spermatogonial depletion (jsd) mutant mice by gonadotropin-releasing hormone antagonist treatment. Endocrinology. 1999; 140:4912-4915. [PubMed: 10499552]

33. Udagawa K, Takeda M, Hosaka M, Kubota Y, Ogawa T. Recovery of spermatogenesis by high dose gonadotropin-releasing hormone analogue treatment in rat cryptorchid testis after orchiopexy. J Urol. 2002; 168:1279-1283. [PubMed: 12187282]

34. Mendis-Handagama SM, Kerr JB, de Kretser DM. Experimental cryptorchidism in the adult mouse: I. Qualitative and quantitative light microscopic morphology. J Androl. 1990; 11:539-547. [PubMed: 1982285]

35. Zirkin BR, Santulli R, Awoniyi CA, Ewing LL. Maintenance of advanced spermatogenic cells in the adult rat testis: quantitative relationship to testosterone concentration within the testis. Endocrinology. 1989; 124:3043-3049. [PubMed: 2498065]

36. McKinnell C, Sharpe RM. Testosterone and spermatogenesis: evidence that androgens regulate cellular secretory mechanisms in stage VI-VIII seminiferous tubules from adult rats. J Androl. 1995; 16:499-509. [PubMed: 8867598]

37. Mendis-Handagama SM, Kerr JB, de Kretser DM. Experimental cryptorchidism in the adult mouse: II. A hormonal study. J Androl. 1990; 11:548-554. [PubMed: 1982286]

38. Lee LPK, Fritz IB. Studies on spermatogenesis in rats. V. Increased thermal lability of lysosomes from testicular germinal cells and its possible relationship to impairments in spermatogenesis in cryptorchidism. J Biol Chem. 1972; 247:7956-7961. [PubMed: 4404838]

39. Jahnukainen K, Ehmcke J, Schlatt S. Testicular xenografts: a novel approach to study cytotoxic damage in juvenile primate testis. Cancer Res. 2006; 66:3813-3818. [PubMed: 16585208]

40. Rathi R, Zeng W, Megee S, Conley A, Meyers S, Dobrinski I. Maturation of testicular tissue from infant monkeys after xenografting into mice. Endocrinology. 2008; 149:5288-5296. [PubMed: 18566126]

41. Gómez MC, Catt JW, Evans G, Maxwell WMC. Cleavage, development and competence of sheep embryos fertilized by intracytoplasmic sperm injection and in vitro fertilization. Theriogenology. 1998; 49:1143-1154. [PubMed: 10732052]

42. Pope CE, Gómez MC, Kagawa N, KuwayamaM, Leibo SP, Dresser BL. In vivo survival of domestic cat oocytes after vitrification, intracytoplasmic sperm injection and embryo transfer. Theriogenology. 2012; 77:531-538. [PubMed: 22015162]

43. Palermo GD, Cohen J, Alikani M, Adler A, Rosenwaks Z. Development and implementation of intracytoplasmic sperm injection (ICSI). Reprod Fertil Dev. 1995; 7:211-218. [PubMed: 7480839]

44. Nakai M, Kaneko H, Somfai T, Maedomari N, Ozawa M, Noguchi J, et al. Production of viable piglets for the first time using sperm derived from ectopic testicular xenografts. Reproduction. 2010; 139:331-335. [PubMed: 20015869]

45. Practice Committee of the American Society for Reproductive Medicine, Practice Committee of the Society for Assisted Reproductive Technology. Round spermatid nucleus injection (ROSNI) Fertil Steril. 2008; 90:S199-S201. [PubMed: 19007630]

46. Gianaroli L, Selman HA, Magli MC, Colpi G, Fortini D, Ferraretti AP. Birth of a healthy infant after conception with round spermatids isolated from cryopreserved testicular tissue. Fertil Steril. 1999; 72:539-541. [PubMed: 10519631]

47. Kimura Y, Yanagimachi R. Mouse oocytes injected with testicular spermatozoa or round spermatids can develop into normal offspring. Development. 1995; 121:2397-2405. [PubMed: 7671805]

48. Ogonuki N, Inoue K, Ogura A. Birth of normal mice following round spermatid injection without artificial oocyte activation. J Reprod Develop. 2011; 57:534-538. 

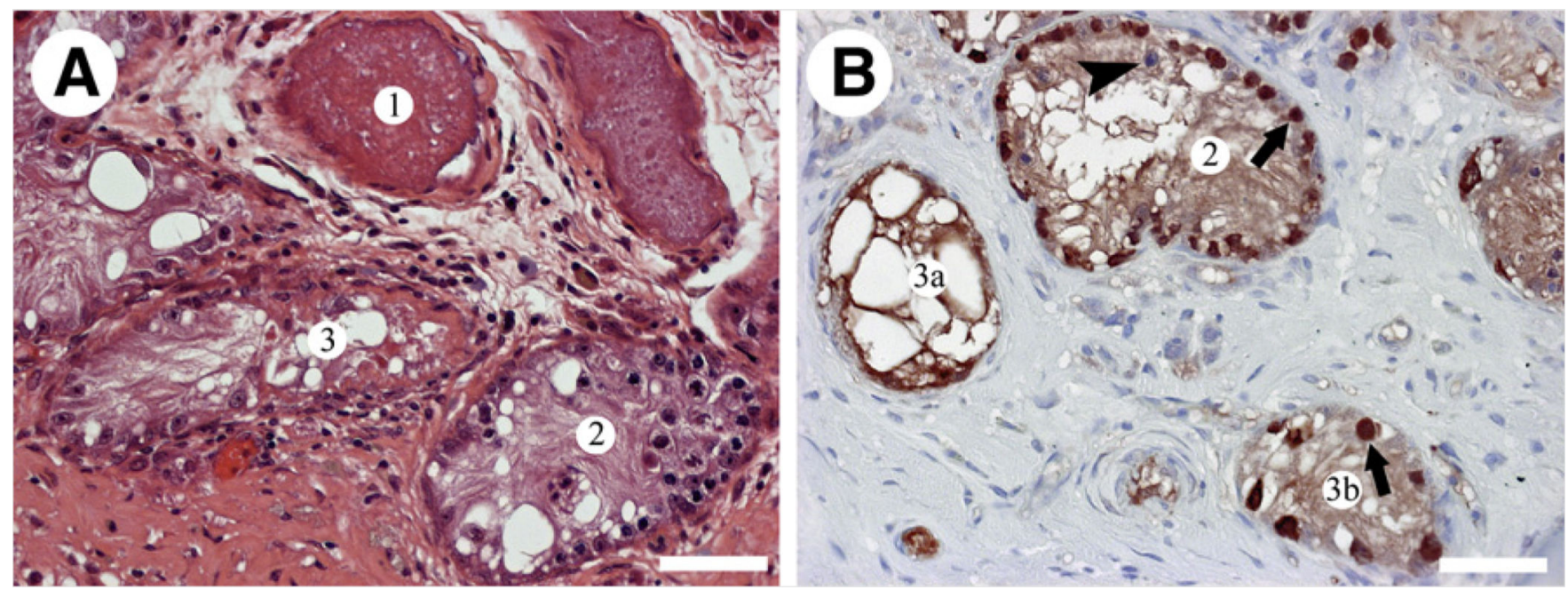

FIGURE 1.

Histologic analysis of testicular tissue grafts. (A) Graft stained with hematoxylin and eosin showing [1] degenerated tubule, [2] tubule with differentiated germ cells, and [3] tubule without differentiated germ cells. (B) Graft after immunohistochemistry for UCH-L1 presenting [2] tubule with differentiated germ cells, [3a] Sertoli cell only tubule, and [3b] tubule with spermatogonia. Spermatogonia are indicated with arrows and spermatocytes with arrowheads. Bar $=50 \mu \mathrm{m}$. 

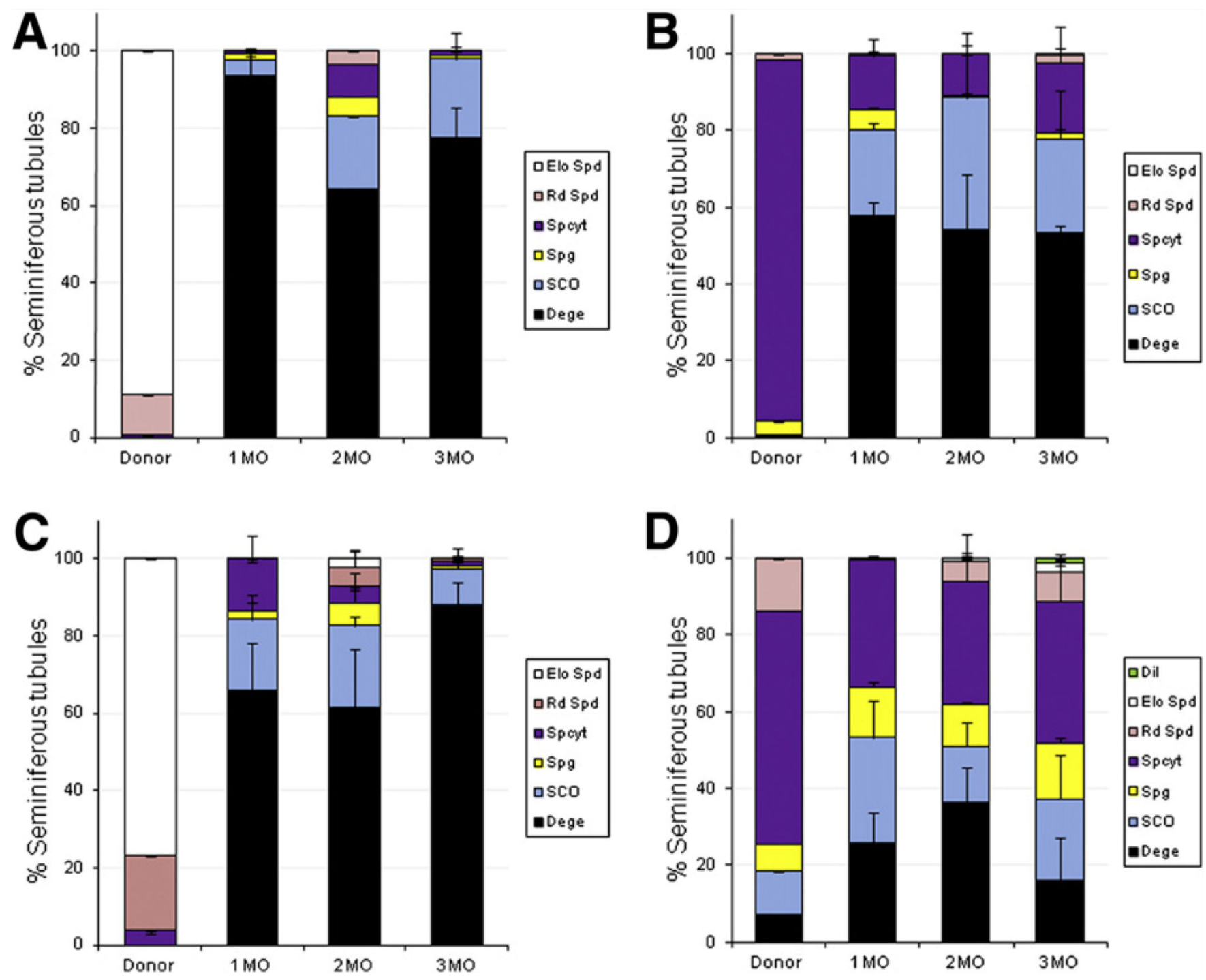

FIGURE 2.

Percentage of seminiferous tubules with most advanced germ cell type in donor testes and grafts. (A) Control tissue, (B) cryptorchid mice, (C) mice treated with $5 \mathrm{mg}$ acyline $/ \mathrm{kg}$, and (D) treated with $10 \mathrm{mg}$ acyline $/ \mathrm{kg}$. Results are means \pm SEM. $1 \mathrm{MO}=1$ month after grafting; $2 \mathrm{MO}=2$ months after grafting; $3 \mathrm{MO}=3$ months after grafting; Dil = dilated; Elo Spd = elongated spermatids; $\mathrm{Rd} \mathrm{Spd} \mathrm{=} \mathrm{round} \mathrm{spermatids;}$ Spcyt = pachytene spermatocytes; Spg $=$ spermatogonia $; \mathrm{SCO}=$ Sertoli cells only; Dege $=$ degenerated tubules . 

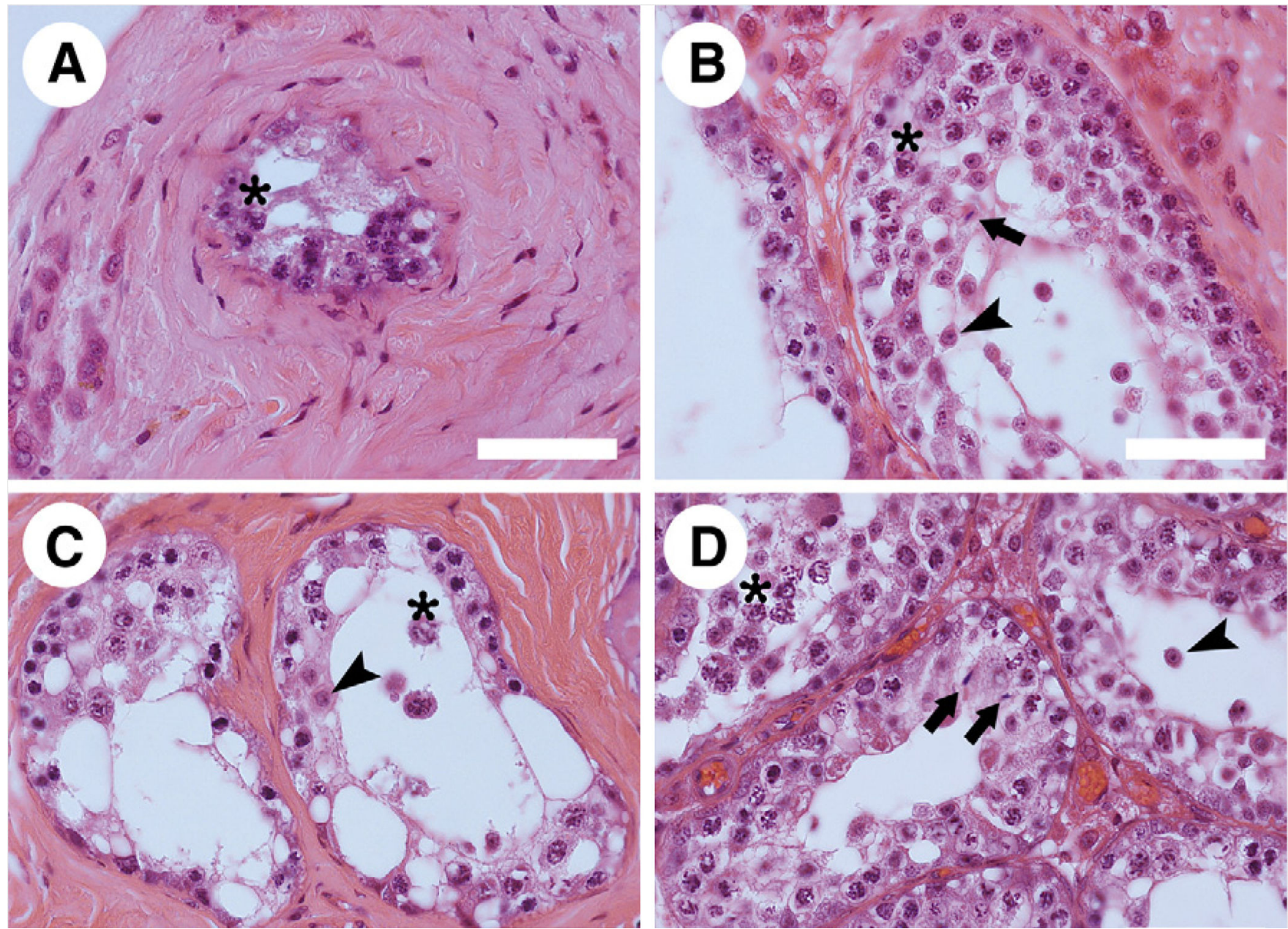

FIGURE 3.

Histologic appearance of adult mouse grafts 3 months after grafting. (A) Grafts from control tissue, (B) from cryptorchid mice, (C) from mice treated with $5 \mathrm{mg}$ acyline $/ \mathrm{kg}$, and (D) from mice treated with $10 \mathrm{mg}$ acyline/kg. Elongated spermatids are indicated with arrows, round spermatids with arrowheads, and spermatocytes with asterisks. Bars $=50 \mu \mathrm{m}$. 


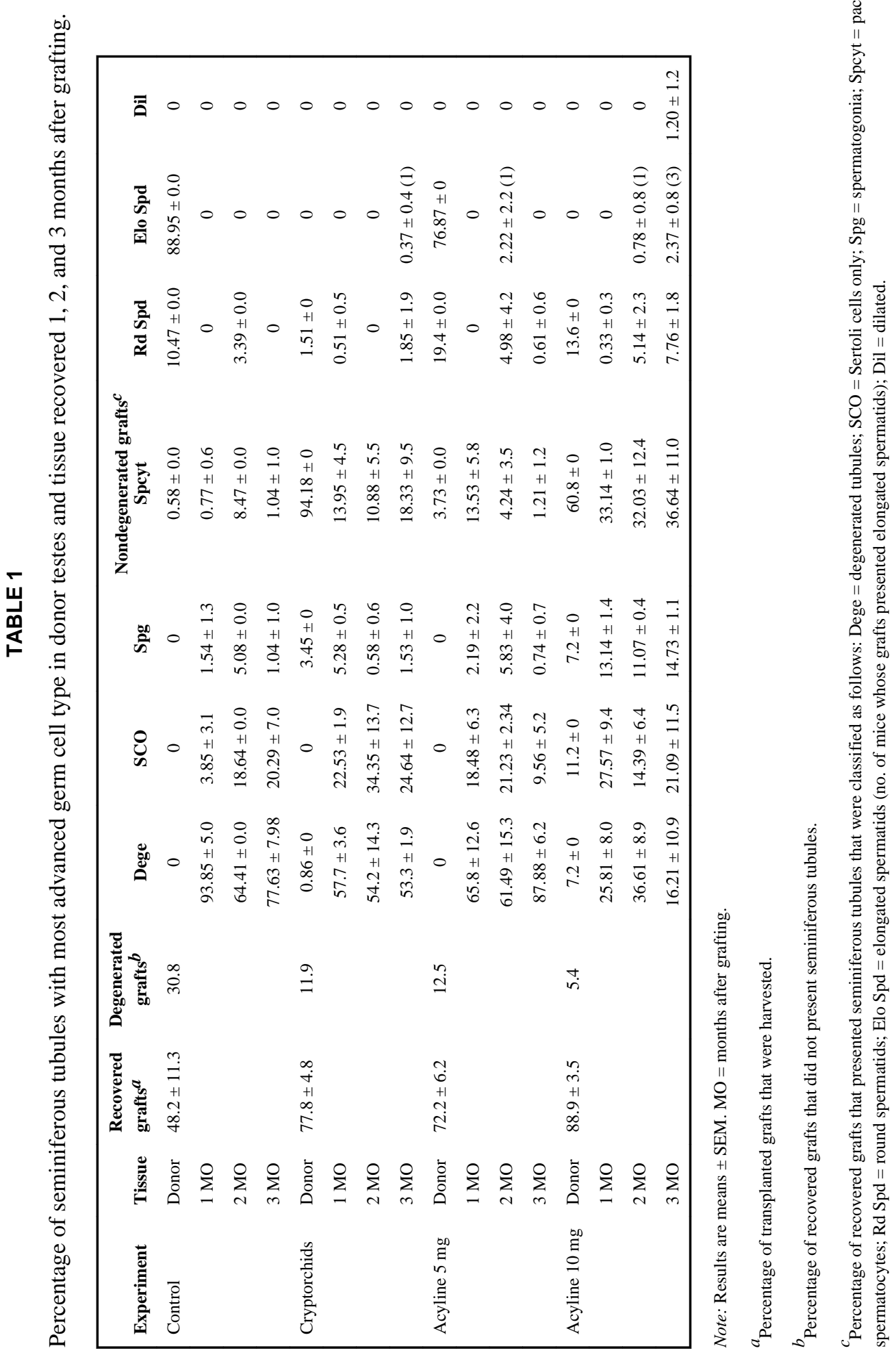

Fertil Steril. Author manuscript; available in PMC 2014 August 12. 